\title{
An evaluation of power relationships among stakeholders in the tourism industry networks of Agra, India
}

\author{
Samrat Hazra $^{\mathrm{a} *}$, John Fletcher ${ }^{\mathrm{b}}$ and Keith Wilkes ${ }^{\mathrm{b}}$ \\ ${ }^{a}$ Department of Business Management, London Churchill College, London, UK; ${ }^{b}$ School of \\ Tourism, Bournemouth University, Bournemouth, UK
}

(Received 22 September 2012; final version received 19 January 2014)

\begin{abstract}
Tourism-related businesses require a multitude of resources in order to operate successfully and given these resources can be accrued from more than one source, bases of power become complex. This is an inductive study which critically evaluates the application of stakeholder theory to an analysis of the tourism destination networks of Agra, India. It examines the relationships of power and dependency that exist between individual and group organisations and the way in which they motivate their behaviour towards each other. The key findings show that resource-based power is formed from the power of individual businesses, the power of the ancillary services stakeholders and the power of the authorities and that network-based power is acquired from the power of agents and the power of groups.
\end{abstract}

Keywords: stakeholder relationship attributes; power; networks; resources; tourist destination management; Agra

\section{Introduction}

Tourism needs to be managed effectively (Chaisawat, 2006; Cooper, Fletcher, Gilbert, Fyall, \& Wanhill, 2005; Fyall, Callod, \& Edwards, 2003) and destinations are central to many tourism activities. These destinations are complex entities, often grown organically but internally connected through networks of groups, organisations and individuals (Fyall et al., 2003), that can affect or be affected by tourism activities as a whole and are referred to as stakeholders (Freeman, 1984; Mitchell, Agle, \& Wood, 1997; Rowley, 1997). Stakeholder theory provides key insights into an effective management and a more useful understanding of the theory of the firm in society (Freeman, 1994; Friedman \& Miles, 2002; Mitchell et al., 1997). The study of stakeholder relationships and how individual and group stakeholders influence a firm's operations (Rowley, 1997) may enhance understanding of the industry as a whole (Fyall et al., 2003; Mitchell et al., 1997). Consequently, power can be an important attribute in stakeholder relationships (Mitchell et al., 1997). Therefore, understanding the power relationships between stakeholders helps to understand the destination, its characteristics and how it is managed now and in the future. Hence, the aim of this research is to examine the power relationships between stakeholders in the tourism industry networks of Agra, India. The objectives are to

\footnotetext{
*Corresponding author. Email: s.hazra@1ondonchurchillcollege.co.uk
} 
(1) examine power as a relational attribute

(2) explore the power concept between stakeholders in the Agra tourism networks

(3) develop a framework to advance knowledge on the power-relationship attributes

Only a few studies have undertaken a detailed analysis of stakeholder networks and relationships either in general (Frooman, 1999; Mitchell et al., 1997; Rowley, 1997; Tsai, Yeh, Shu-Ling, \& Ing-Chung, 2005) or specifically with respect to the tourism industry (Pavlovich, 2003; Scott, Cooper, \& Baggio, 2008).

Power, for the purpose of this study, is defined as the ability of one entity to influence the behaviour of another entity (Mitchell et al., 1997; Ujma, 2001) and the first step is to examine inter-stakeholder influence and to attempt to identify its strength for each stakeholder. Although the strength of influence can emanate from a variety of sources, it is the control of resources needed by others to carry out their businesses that determines the strength and direction of power this is referred to as 'resource-based power'. Resources in this context are broad in nature and defined to be anything a stakeholder perceives to be valuable (Frooman, 1999) and which is necessary to operate their business. Tourism resources can include land, labour, capital, energy supply as well as access to customers (Aitken \& Hall, 2000; Brammer \& Beech, 2004; Cooper et al., 2005; Nepal \& Chipeniuk, 2005; Ritchie \& Crouch, 2005) and other intangible resources such as knowledge and expertise (Coles \& Church, 2007; Cooper, 2006).

However, having resources per se do not necessarily result in an effective production (Amit \& Schoemaker, 1993; Burney, 1991) because they need to be processed in some way to realise the end product. Resources need to be processed through groups and individual stakeholders within a particular channel or network and this becomes the value-added delivery system. It can be configured along a value chain involving many activities and can be vertically, horizontally and/or diagonally related and integrated to varying degrees (Fill, 2006; Klaus, 2006; Kotler, Bowen, \& Makens, 1999; Weiermair, 2005). Therefore, tourism can be seen to be the result of joint action by various stakeholders working towards the common goal of satisfying tourism needs and demands.

Resources (such as patents and licenses; financial or physical assets, such as property, plant and equipment; human capital, etc.) are tradable and desirable goods/services for value chain participants. But resources are only effective if distributed and traded through channels or networks (Pajunen, 2006; Rowley, 1997). And effective distribution of resources is the key to sustainable development as suggested by Holden (2010) and Saarinen (2006).

Power is not derived solely by being in a chain of value; it is derived from holding a position within that chain (network) that controls the flow of resources (Pajunen, 2006; Rowley, 1997). This is known as 'network-based power'. Network-based power refers to power obtained through the network's structure as opposed to power gained through the resources' inherent attributes (Pajunen, 2006). Network positioning can be referred to as network centrality and it is this that helps determine a stakeholder's network-based power (Rowley, 1997).

Many researchers (such as Buhalis, 2000; Carey, Guontas, \& Gilbert, 1997; Cooper et al., 2005; Holden, 2010; Morgan, 1996; Ritchie \& Crouch, 2005; Sautter \& Leisen, 1999; Weiermair, 2006) have applied stakeholder theory at the destination level, which, in effect, treats it as if it were a single entity comparable to a commercial organisation. These studies also tend to focus on destination management organisations (DMOs) and policy-makers, rather than recognising them as a diverse group of stakeholders (with a few exceptions, see, for example, Pavlovich, 2003; 2008; Scott et al., 2008). Therefore, 
there has been a tendency to underestimate the importance of the dynamics of stakeholder networks within a destination.

This study contributes to understanding stakeholder behaviour by critically evaluating the roles and influences of the relationship attributes of the individual and group stakeholders within the tourism destination of Agra, India. Much of the stakeholder and network research has been conducted in the contexts of western or industrialised nations. This study, being based in India, reveals issues from both the perspective of an eastern nation and that of a rapidly emerging economy. This brings new knowledge and understanding to the stakeholder relationship management phenomena. The main tourist attraction in Agra is the Taj Mahal (the Taj), which is a United Nations Educational, Scientific, and Cultural Organisation (UNESCO) World Heritage Site (Edensor, 1998). It attracts an average of $2.5 \mathrm{~m}$ of which $2 \mathrm{~m}$ domestic and $0.5 \mathrm{~m}$ overseas visitors annually (Ticket Sales Record - Agra Calling, 2010) and, as such, helps provide a substantial amount of money (around $£ 5 \mathrm{~m}$ ) for the destination and the region as a whole.

The fact that Agra is a destination where the major attraction, the Taj, is outside the control of local policy-makers presents a similar situation to that found in areas that are home to attractions such as the Victoria Falls, Stonehenge and the Great Wall of China. Consequently, the management of the destination is complex and can create tensions between the stakeholder groups and the attraction owners/controllers (Hannam, 2004). Issues of power and control over resources can generate matters of controversy sometimes leading to open and fraught debates in the destination and beyond (Kimbu \& Ngoasong, 2013). The controversial nature and its significance to stakeholders meant that participants were not only able, but also ready and eager to talk about their relationships with other stakeholders, making it easier for the researchers to gain access to rich data relating to this topic.

\section{Review of the literature}

Power is a central issue in tourism research when diverse stakeholders confront unequal power relations resulting in conflicts (Hannam, Sheller, \& Urry, 2006). Scherle and Coles (2006) conceptualised power as being subjective in nature and thus difficult to define. Ujma (2001, p. 38) observes power as 'the ability of one channel member to get another channel member to do what it otherwise would have not done'. Mitchell et al. (1997, p. 865) find that even though power may defy definition it is not difficult to recognise: '[it is] the ability of those who possess power to bring about the outcomes they desire'.

If a business depends on critical resources for its survival and those resources are controlled by specific stakeholders, the stakeholders will have absolute power over that business (Scott, 2006; Tsai et al., 2005). Therefore, the degree of power is determined by the relationship of the dependence (Frooman, 1999; Scott, 2006).

The multi-sector nature of tourism leads to particular difficulties in understanding how to deal with multiple power relations among stakeholders where unitary interests are lacking (Luke, 2005; Scherle \& Coles, 2006). As Cooper et al. (2005) and Ritchie and Crouch (2005) find, tourism businesses not only compete with each other but they also complement and cooperate. Consequently, the duality of independence-interdependence is at the heart of a series of distinctive power relations resulting from this interaction (Scherle \& Coles, 2006) making power a contested concept within the tourism industry. Resource dependence theory operationalises power (Frooman, 1999, p. 196): 'for the 
dependence between two organisations to provide one organisation with power over the other, there must be asymmetry in the exchange relationship'.

Resource-based power 'is obtained through the possession and control of resources that are valued by another party' (Stern \& El-Ansary, 1992, p. 268). These resources are the assets and conditions within a relationship that generate and represent each channel member's dependence, gratitude, loyalty or trust to another. Such arguments support Burney (1991) whose conceptualisation of 'resources' includes all assets, capabilities, organisational process, firm attributes, information, knowledge, etc. controlled by a firm that enable the firm to conceive of, and implement, strategies that improve its efficiency and effectiveness. Stakeholders value each other's resources; otherwise, they would not do business with one another. Therefore, power is a 'two-way street' (Stern \& El-Ansary, 1992, p. 268).

Network theory also encompasses the collective nature of organisational actions, constraints and coordination (Pavlovich, 2003). It assumes that 'relationships do not occur within a vacuum of dyadic ties, but rather in a network of influences, where a firm's stakeholders are likely to have direct relationships with one another' (Rowley, 1997, p. 890). Network analysis provides a means for examining how the pattern of the relationships, the 'interaction of interactions', in a stakeholder environment influences an organisation's behaviour (Rowley, 1997, p. 894).

Granovetter (2004) refers to the existence of strong and weak ties within social networks. Weak ties are difficult to identify and tend to be informal. Stronger ties come when there is similarity (Granovetter, 1983, 2004). People with similar characteristics and needs tend to create strong-ties which often lead to formal networks which are easily identified. This research deals with formal networks. Granovetter's work is largely based on sociological and psychological views with a social purpose. Social values might also be important in the tourism industry networks, but profit-related values are more likely to dominate.

Pavlovich (2003) takes a dynamic approach focusing on how changing relationships between organisations creates an environment for self-organising. This study uses network theory to express this dynamism and emphasises structural features of density and centrality. Pavlovich (2003) identified the need to understand how connectivity and information exchanges help build stronger coherency within destination networks. This approach moves the focus away from an individual firm to one that looks at networks which is more appropriate to the tourism industry.

Although Scott et al. (2008) used a quantitative approach to examine the developments in tourism networks, their studies concentrated on developed nations and structural network properties. However, they do not explore the causes of development and its implications on stakeholder relationships and the destination itself.

Representations of relational data are found in the overall structure of the network (density) and the nodal position within the network (centrality) and this embodies the characteristics of resource dependence theories (Pajunen, 2006; Pavlovich, 2003; Rowley, 1997). Three types of centrality are commonly discussed each corresponding to a different aspect of a stakeholder's positional status. They are degree, closeness and betweenness and can be used to measure ties between, control over and independent access to actors (Pajunen, 2006; Rowley, 1997). Hence, this research investigates 'power' as an attribute in two distinct ways: resource-based power and network-based power in the Agra tourism network (see Figure 1). 


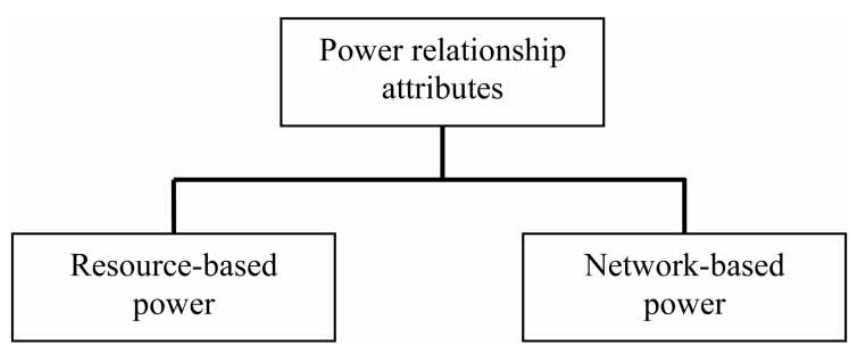

Figure 1. Resource- and network-based power.

\section{Research methodology}

An interpretative-qualitative methodological approach was deemed appropriate for this research as it sets out to explore relationships, experiences, behaviour and perceptions which are difficult to quantify (Gratton \& Jones, 2007; Silverman, 2006; Zapata, Hall, Lindo, \& Vanderschaeghe, 2011). To achieve the research objectives a series of interviews were conducted in the summer of 2010 (April-July) with key tourism stakeholders using a snowballing technique where the participants identified the key stakeholders within the Agra tourism networks. Snowballing was chosen as an aid to identify diverse stakeholders in the network. Interviews were designed to identify stakeholders' attitudes and experiences with respect to their relationships with other members of the networks as supported by researchers including Stampe (2008), Wilson and Little (2008) and Holden (2010). In particular, interviews allow the extra freedom of engaging in a dialogue to access enhanced levels of information (Denzin \& Lincoln, 2000; Miles \& Huberman, 1994; Saunders, Lewis, \& Thornhill, 2009; Yin, 2003).

The interview checklist was developed from the key themes shown in Figure 1, and as the interviews progressed, the checklist was modified to meet the objectives of the study. Tourism resource dependency and network centrality related questions were used to determine the key resource needs of tourism businesses and how those resources were traded through the networks. The checklist also included questions to investigate sources of such resources, their effect on relationships, managing the flow of resources and how stakeholders counterbalance such power bases.

The primary researcher (Indian origin) took the leading role to conduct 34 in-depth interviews with prominent figures in the tourism industry networks of Agra who were either commercial or non-commercial stakeholders. The interviewer's identity helped facilitate the interviews because of his awareness of local culture, traditions and the industry itself. The initial resistance to providing information was overcome by assurances over the use of the data and the manner in which it will be disseminated. This suggests that the networks, although intended to transmit information and views, are populated by stakeholders wary of being identified as holding those views. The researcher initially identified the gatekeepers of the Agra tourism industry, i.e. leaders of the associations, tourism groups and trade unions, and after gaining their consent and trust, was introduced to other members of the networks and interviews progressed in this snowballing fashion.

The interviewees included informants from seven hotels, three restaurants, five tour operators (TO), five travel agents (TA), three local authorities (Agra Development Authority - ADA, the Mayor of Agra and Archaeological Survey of India - ASI), a member of the Chamber of Commerce, two tourism officers (State Government Tourism Office- 
Uttar Pradesh and India Tourism Office run by the Central Government), three emporiums, three tour guides (TG) and two members of the Hotel and Restaurant Association and the Tourism Guild.

The informants were selected from managers and business owners who could speak authoritatively about the issues. The interviews were conducted in 'English', a widely spoken language among the trades people (also supported by Bandyopadhyay, Morais, \& Chick, 2008 in their research conducted in India). Interviews were transcribed on a daily basis to look for emerging themes and to further develop the interview checklist to achieve greater depth (Holliday, 2007). Findings emerged as the interviews were analysed thematically (Figure 1) and additional themes emerging from the interviews.

\section{Findings and discussion}

\section{Tourism resources}

With respect to resources, almost all of the interviewees agreed that the generic resources needed for any kind of tourism-related organisation must include land, labour, capital, knowledge and skill and access to customers. As an example, a respondent (Emporium Owner) stated:

Main tourism resources are location, money, workers. My father was in this business. I worked with my father. I have experience in this field. I need customers to sell my products too ... (Q1)

This identifies that a fundamental resource needed to operate a tourism-related business often includes location (land on which to build the establishment), money (capital to establish the operations and functions of the business), workers (labour force needed to run the business), knowledge (knowledge in general to operate the businesses: in this case it can be conceived also as 'experience' which is tacit knowledge) and clients.

Besides this, a group of other, more specific, resources were identified from the interviews. For example, in order to see what resources the interviewees perceived as valuable, the approach by Frooman (1999) was adopted using an open question to stimulate the discussion (what do you need to run your business?). The answers ranged from supplies of tap water, electricity and building materials to the maintenance of roads. The diversity of these specific resources was also noted by Amit and Schoemaker (1993), Amujo and Otubanjo (2012), Cooper et al. (2005) and Ritchie and Crouch (2005). At the macro-level, the resources they need to carry out their business include everything at the destination. A TO stated:

We need everything really. The list can range from all the basic needs of a business and on top of this the business environment is really important. Need good roads, clean roads I mean without pot holes, clear drains, building materials, hospitals, post offices, staff, etc. And banks. How many banks have you seen on this road? Need more. The other thing, maintenance of the Taj Mahal very important for my business. All the time Taj should be very very clean and well maintained ... (Q2)

This statement reveals some frustration at the lack of control over the maintenance of some facilities and also demonstrates the lack of resources necessary for the successful operation of businesses. In relation to that and demonstrating the recognition of the two-way relationship (as suggested by Stern \& El-Ansary, 1992) between tourism and the local industry, the Mayor of Agra stated: 'Tourism needs everything and everything needs tourism' (Q3). 
The identification of a lack of resources was not a universal view and some suggested that it was more important that coordination and cooperation were greater priorities, as stated by a member of the local government from the ADA:

There are plenty of tourism resources. Actually tourists need everything in the city to make them happy, have a good experience. We care about infrastructure; someone else cares about something else. ADA want funds, which come from tax and donations. Our income is good. Everybody want [s] to work together for [a] better Agra. I tell you, working together will solve many problems. (Q4)

This illustrates the demand and dependency of the tourism industry in Agra. It can also be seen from the data that, at the individual stakeholder level, the focus is on the resources and although the list is quite extensive, it varies from business to business and organisation to organisation, depending on size, type, nature of ownership and location. One resource commonly referred to was energy supplies. In a rapidly growing Indian economy, industries are constantly pushing the boundaries of available energy supplies and hence power cuts have become a regular occurrence, even in Agra which suffers them several times each week. Whereas in many places alternative sources of energy can be generated, attempts to protect the Taj means that oil power generators are not allowed to run within the Taj Trapezium Zone (TTZ), an area of $10,400 \mathrm{~km}^{2}$ around the Taj to protect the monument from pollution. The TTZ covers over 40 protected historical monuments including three World Heritage Sites, i.e. the Taj, Agra Fort and Fatehpur Sikri (Edensor, 1998). Thus, if a business/organisation is within this zone, then either the generator has to be set outside the zone or an alternative smoke-free method must be used. These restrictions impact on business location decisions and the result may not always be optimal from a tourism development point of view.

\section{Resource-based power}

The wide variety of resources needed to operate a tourism-related business in Agra can be accrued from a range of sources and so resource-based power is not confined to a few single entities. This adds complexity to network relationships and obscures the ownership of resource-based power. To add to the complexity, resource owners can be in control of more than one type of resource.

The literature shows that resources, if considered as isolated factors, do not result in productivity, hence the coordination of resources is important (Fill \& Fill, 2005; Harrison, Hitt, Hoskisson, \& Ireland, 2001) and along the value chain (Klaus, 2006; Kotler et al., 1999; Porter, 1985; Weiermair, 2005) the processes of stakeholders add value to these resources to create tourism products. A personnel manager of a major hotel commented:

We deal with hotel rooms. Then we need transportation to take guests to the Taj. Then food, water, tourism offices, souvenir shops, TGs, financial services, security services and so on. Hotels alone cannot do anything. It has to be a chain of activities put together to please a customer. We need each other. (Q5)

This quote was typical of members across a wide spectrum of sectors in Agra during the interviews. It is also a view supported by Stern and El-Ansary (1992), who state that organisations are the primary entities which have been created to put resources together in such a way that the output from the combined resources is greater than the sum of the individual 
parts. Thus, it is difficult to identify any individual stakeholder or organisation that can be used to study resource relationships, e.g. resource-based power.

In an attempt to understand resource-based power more fully, the uses of these resources were categorised, so that associated behaviour, characteristics and relationships could be analysed. The categorisation of resources resulted in the emergence of patterns that helped to achieve better understanding. The categorisation isolated resources according to their need in day-to-day, year-to-year and long-term tourism activities. The research broke the resource-based power down into: power of individual businesses, power of ancillary services stakeholders and power of the authorities.

\section{Power of individual businesses}

Many businesses are small, family run affairs making the industry quite fragmented in Agra as it is throughout the world. Each small business contributes towards the survival not only of their own business, but also to the survival of other businesses in Agra and towards tourism as a whole. It is evident from the interviews that, as well as needing various resources to run their organisations, individual businesses also need each other in order to process those resources (Q3 and Q5). A TG sums up well:

Everybody has power in this area. Think carefully, I am a Guide. People may think that I am not valuable. But without us no-one there to show tourists around. We know this place like back of my hand ... if I don't work, think about the consequences. Same with the other businesses. My friend, tourism is a complex industry. You seen 'Spider Net'? If one member does not co-operate, the whole industry can suffer ... (Q6)

Each stakeholder has some resources in stock (Amit \& Schoemaker, 1993 Burney, 1991); therefore, they will have some power at the individual level within the network. This kind of power can be referred to as the 'power of individual businesses'. Interviewees felt that, without resources like rooms, restaurant covers or emporiums, the tourism industry as a whole would come to a standstill. In reality, without them there is no tourism industry. Almost all the interviewees agreed with this view. A Hotel Owner explains:

... I have power in Agra, if I close my hotel where do you think the tourists are going to stay? I know I will lose business ... Same goes for Emporiums. If they close, nobody can buy souvenirs. Restaurants, suppliers, TGs, etc. If we cease our operation, the authorities can't do much.

We may be small and fragmented, but we have power too. (Q7)

Stakeholders exploit the available resources in order to create and meet tourists' needs and demands. Individual tourism businesses collectively provide an amalgam of products and services to serve the industry as a whole. They create a legacy of the tourism product which extends beyond the immediate satisfaction levels and promotes future potential tourism activity. Thus, individual tourism businesses can also be labelled as 'tourism resources'. If a single one of them does not cooperate or run adequately, the effect on Agra's tourism industry may be profound.

All organisations and businesses have roles to play in Agra and all have to meet the needs of the different tourism markets. Individual businesses are especially crucial in day-to-day tourism operations, as one of the interviewees mentions 'every business counts in Agra' (restaurant owner, Q8). It implies that the closure or mismanagement of one of these businesses could have wide spread effects on the industry and the region itself. 


\section{Power of ancillary services stakeholders}

Stakeholders and organisations that are not directly related to tourism can also be important to the successful and smooth running of a tourism destination. These organisations can be labelled as ancillary services (Buhalis, 2000; Burkart \& Medlik, 1981; Cooper et al., 2005). They could be semi-government establishments including banks, post offices, hospitals, news agents and telecommunications. The interviewees thought that without the presence and effective operation of these organisations, individual businesses along with the tourism industry as a whole would face difficulties both in their day-to-day operations and consequently in their year-to-year strategies and beyond (Q2 and Q5). These services are shared by organisations related to tourism and the tourists themselves. The importance of the 'ancillary services stakeholders' was recognised by tourism stakeholders in Agra. According to Fill (2006), ancillary services stakeholders are included mostly in the tourism support network. Ancillary services stakeholders can exercise their power in different ways. Banks and telecommunications systems are the prominent examples, as one TO recites:

Banks are useful for everybody. Many clients not always exchange their money in Delhi. They change it in Agra too. If Agra does not provide this service then it will be a big problem for my clients. Same goes with phone services. If they go on strike ... [long pause] what is going to happen? Can you imagine Agra without them? (Q9)

Clearly, ancillary services stakeholders are important in the operation and survival of the tourism organisations in Agra. Hence, understanding the resource-based power of the ancillary services stakeholders in tourism industry networks is useful in stakeholder relationship management studies.

\section{Power of the authorities}

The 'authorities' in Agra relevant to this research include the local government, the Mayor's Office, ADA, ASI and the India Tourism Office. These authorities hold, manage and control some of the most important tourism resources including capital, labour, land and knowledge in Agra. Authorities are involved in mostly 'long-term' policies and regulations. There could be policies which are specific to tourism or other policies which may affect tourism in some way. The Central India Government helps (financially) the tourism and hospitality educated people establish their tourism-related businesses through a special State Bank of India loan scheme (Kamat, 2002). Thus the government along with the Tourism Finance Corporation of India Ltd. encourages tourism development by injecting expertise to the industry. Likewise, the number and quality of TGs are maintained through the official bodies (i.e. ASI and India Tourism Office in Agra) in Agra.

There are two main types of TG in Agra, qualified and unqualified. However, both types of guides may have the ability to perform through different skill sets. Unqualified TGs work from their experience in the field over a long period of time usually having gained the skill from their forefathers. They require memberships of the Tour Guide Association which ensure their credibility of working in Agra. However, no new unqualified-tour-guide licences are issued. Qualified TGs have to gain the necessary qualifications to work in Agra. It might be a lengthy process but it is a rigorous one. This type of TG receives education and training, including learning different languages, in order to enable them to carry out their job at a professional level. 
The development of qualified TGs should enhance the tourist experience and, in the long run, benefit the industry. Jointly the ASI and India Tourism Office set the criteria by which TGs can become qualified and arrange examinations. Successful candidates receive a permit or licence to work as a TG and have to renew their permit after a certain length of time.

Tourism-related establishments could be built in any location within Agra until recently. Now, however, tourism development is restricted to 189 ha of land reserved solely for that purpose. Although clearly restrictive, this also simplifies the planning procedures; for example, if someone wants to build a hotel on land designated for tourism development, all other consents (licences and permits) will be given automatically. This is easier than going through the various departments for each of the different permits. However, the local government is in control of the land and sets criteria for the standards and scale of any proposed tourism development. Both multinational large and domestic small organisations are subject to this control. This gives the authorities more power to control potential tourism development in Agra.

One of the owners of a producer and distributor of souvenirs (specialising in cotton goods) explains his view about the power of the local Mayor in Agra:

I together with others may influence the tourism policies, but ultimately it is the government or the Mayor of Agra who decides on the issue and problems ... (Q10)

Another source of control is identified as being the ADA which responded by saying:

\begin{abstract}
Any construction of any buildings including international or domestic tourism has to go through us. We are a big establishment. We have to look after this heritage-city. You cannot just make anything here. Come on - do you not agree? There must be rules and regulations. We need to look into different things, for example water supply, drainage, location and so on. (Q11)
\end{abstract}

Therefore, the resources of the government and local authorities are not only important but also, in some cases, a mandatory requirement in the operation and survival of tourism organisations in Agra. The study of resource-based power opens new doors to our understanding of such complex relationships. However, as is shown in the literature (Pajunen, 2006; Pavlovich, 2003), resource-based power alone does not explain the power of intermediaries and agents, because they do not hold and/or own resources as such but can channel them as they wish. The following section analyses some of these issues in detail.

\title{
Network-based power
}

It has been shown that power can stem from a number of sources (Q2, Q6 and Q7). It has also been shown from the above analysis that resources are only effective if distributed and traded through a channel or a network (Q5). Thus, power can also stem from the position held in the network which may control the flow of resources. This is known as structurebased forms of power or network-based power (Pajunen, 2006; Rowley, 1997) or the capability (as described by Burney, 1991) of an organisation to accrue such a role within the network to distribute resources. There are two prominent examples of structure-based forms of power found in the Agra tourism network. There is evidence of power of agents and power of groups, respectively. 


\section{Power of agents}

In this context, 'agents' are those who comprise a link between the various parties or resources. Agents share the resources according to the material benefit they receive by trading those resources. In Agra, the tourism industry agents can range from TAs, TOs, TGs, taxi drivers, tourism offices and other tourism establishments (i.e. anybody who can/has opportunity/power to pass clients/business to others). According to the perception of those interviewed, an agent's power (i.e. TA and TO) is one of the types of network-based power evident in the tourism industry network in Agra. A member of the tourism network discusses:

Both TO and TA business is done here. I deal with domestic and foreign clients. I have power to deal with the hotels and bring customers to Agra. If we are not happy with the situation we can divert our clients to somewhere else. (TO and TA, Q12)

Businesses and organisations in Agra may have other sources through which to get clients, but most of them consider these travel intermediaries as a major source:

... hotel is running on the mercy of the internet and the TO. And sometimes the taxi and auto drivers bring customers from the rail station. We are connected to both TO in Delhi and outside. They are happy with us and we are happy with them ... We can't lose them (TOs). They keep us going... (Hotel, Q13)

The power of agents can be defined as 'betweenness centrality' which measures the frequency with which an actor falls on the paths between pairs of other actors (as defined by Pajunen, 2006; Rowley, 1997). Betweenness centrality captures an actor's ability to control others. According to these authors, actors with a high betweenness centrality are brokers, agents or gatekeepers in the sense that they facilitate exchanges between less central actors. Agents, such as TOs and TAs, have a high betweenness centrality because, as was found earlier on, in the context of Agra, they control the flow of clients to various businesses. This also refers to Frooman's (1999) explanation of 'controllability'. These individual stakeholders have access to clients and lay across the path between clients and other service providers (such as hotels, emporiums and attractions). These travel intermediaries have network-based power to control the flow of clients into the city and to different organisations within Agra. Up to a certain extent this is countered by other agents in the network who then further distribute the clients within Agra, as found earlier on, they include TGs, taxi drivers and individual businesses. This refers to Frooman's (1999) 'substitutability' of resources.

Agents can exploit their network position by distributing clients to other businesses in any way they wish. A well-known example of such an agent would be TGs in Agra, who take clients to the emporiums for souvenir shopping. Therefore, it falls upon the TGs to choose an emporium. As an incentive, emporiums give TGs a commission to bring the clients to their particular shop. TGs have the 'power of agents' to bargain for commissions. The quote below shows the power of agents of both the travel intermediaries and the TGs:

I depend on TO a lot. This is a part of a tour operating company any way. But the thing is ... our company does not have offices in foreign countries, and foreigners book their holidays through them. So for example if they don't include our emporium in their trip, we miss out. TO receive commission for that. TGs also receive commission. If its not good commission ... They go somewhere else ... (Emporium Owner; Q14) 
It is also suggested that travel intermediaries and agents try hard to get the best deal out of the tourism businesses. They would exploit their power to negotiate with the respective organisations. Thus, businesses form alliances to protect themselves from any unfair deals. Therefore, the next section explores and evaluates the bases of such power of groups in the Agra tourism context to understand better their relationship and behaviour.

\section{Power of groups}

Groups can be defined by collective behaviour or achievement. Groups have collective bargaining power on their side (Kotler et al., 1999). Their activities are influenced by their circumstances. The majority of the participants believe that, individually, it is hard to control the power of these agents, policy-makers or any outside forces. Individual businesses can be bypassed easily by intermediaries and authorities in the network. In their opinion, it is beneficial for individual businesses and the industry as a whole to form alliances. This formation creates what is known as the 'power of groups' which could be considered as power of unity, which in turn then empowers individual organisations. According to Granovetter (2004), these bonds are part of strong-ties where, for example, in a business scenario actors can be a part of a group or association to optimise business dealings resulting in greater profit margins. An experienced owner of a cottage industry emporium demonstrates the strength of these groups by giving an example of one of their achievements:

... Again when we work as an association our power even increases against authorities and other businesses. This is called the power of unity. Especially for cottage industry the wool comes from New Zealand and we used to pay a lot of tax. They protested through industry associations. Now the government gives discounts on tax for buying wools ... (Q15)

A member of these groups also can receive extra benefits compared with non-members. An association member further emphasises that:

... You have to know the people in the industry well. Without them you won't get customers. In our industry you can't survive in isolation. You have to have knowledge about what you are doing of course. If you are new in the business ... Join our group. We will help you throughout ... (Hotel, Q16)

Stakeholder groups are the bodies that bring together various tourism stakeholders under one umbrella, as supported by Granovetter $(1973,2004)$ being part of strong-ties in a formal relationship network for mutual benefit. This can also be identified as another kind of network-based power which has the characteristics of 'closeness centrality' described by Rowley (1997) and Pajunen (2006) as one the components of network theory. Closeness centrality defines an actor's ability to access independently all other members of the network. The 'power of groups' as in the form of a single body would allow independent access to others in the network. By forming alliances, collectively they could work in a 'pack' to defend their interests and draw collective benefits. Unlike an individual, the group as a whole can control the flow of resources through the network because of its collective bargaining power. Hence businesses/stakeholders form associations and unions. 
Authorities (such as tourism offices, ADA and ASI) have to consult with and get consent from the trade bodies for any tourism-related planning and development activities in Agra. For example, these bodies have claimed in these interviews to have successfully argued for the provision of land reserved for tourism development, for the reduction of the 'luxury' tax on hotel rooms and prevented an increase of entry fees to the Taj.

On the other hand, the literature also associates closeness centrality with efficient communication, stating that closeness means fewer message transmissions, shorter times and greater efficiency. As the official voice of the tourism industry, these bodies can communicate directly with others in the network and vice versa. The regional tourism office in Agra says that:

... through Association and Guild we pass lots of tourism information. Otherwise it is impossible to reach them individually. Saves time, yes. See, they have meetings among themselves and they pass our message. For example the Taj Mahasav, such a big gathering of tourists and locals. Need to spread so much information. Tourism offices have leaflets too ... (Q17)

Like information, the majority of the businesses feel that knowledge, as one of the fundamental tourism resources (Foster, McCabe, \& Dewhurst, 2010), resides in these networks. Knowledge becomes crucial in industries like tourism where stakeholders not only cooperate to present a coherent tourism destination, but also compete with each other in the domestic and overseas markets. This is supported by the literature and also in this study where some of the interviewees stressed that knowledge can be exchanged as a 'gift' through connections and conversations within networks. This can only happen if the exchange of knowledge is based on trust, mutual respect and reciprocity.

Multinational and chain organisations can develop and share knowledge within their internal networks. Other smaller or independent firms in the tourism system have to learn and gain knowledge through different sources. Access to knowledge and skill is not straight forward. Tacit tourism knowledge cannot be bought or applied for - it needs to be gained through experience.

Analysis of the data reveals that one of the important sources of knowledge is that which comes from belonging to a formal network within the destination (Q16 and Q17). Formal networks for tourism businesses in Agra could include membership of these trade associations, Chamber of Commerce, etc., where members discuss and act together on different issues, solve problems and show guidance. One of the interviewees admits that, as a newcomer to the tourism business in Agra, membership of one of these bodies brought invaluable benefits to the business. In that respect, these trade associations have network-based power over knowledge and skill.

\section{The framework}

Figure 2 shows the power-relationship attributes, expanding the groups identified in Figure 1 by using the findings from the stakeholder interviews in the Agra tourism networks. It illustrates a comprehensive framework of stakeholder power-relationship attributes and how the resource-based and network-based power chains are formed. The figure clearly shows the different actors populating the different power-based columns. 


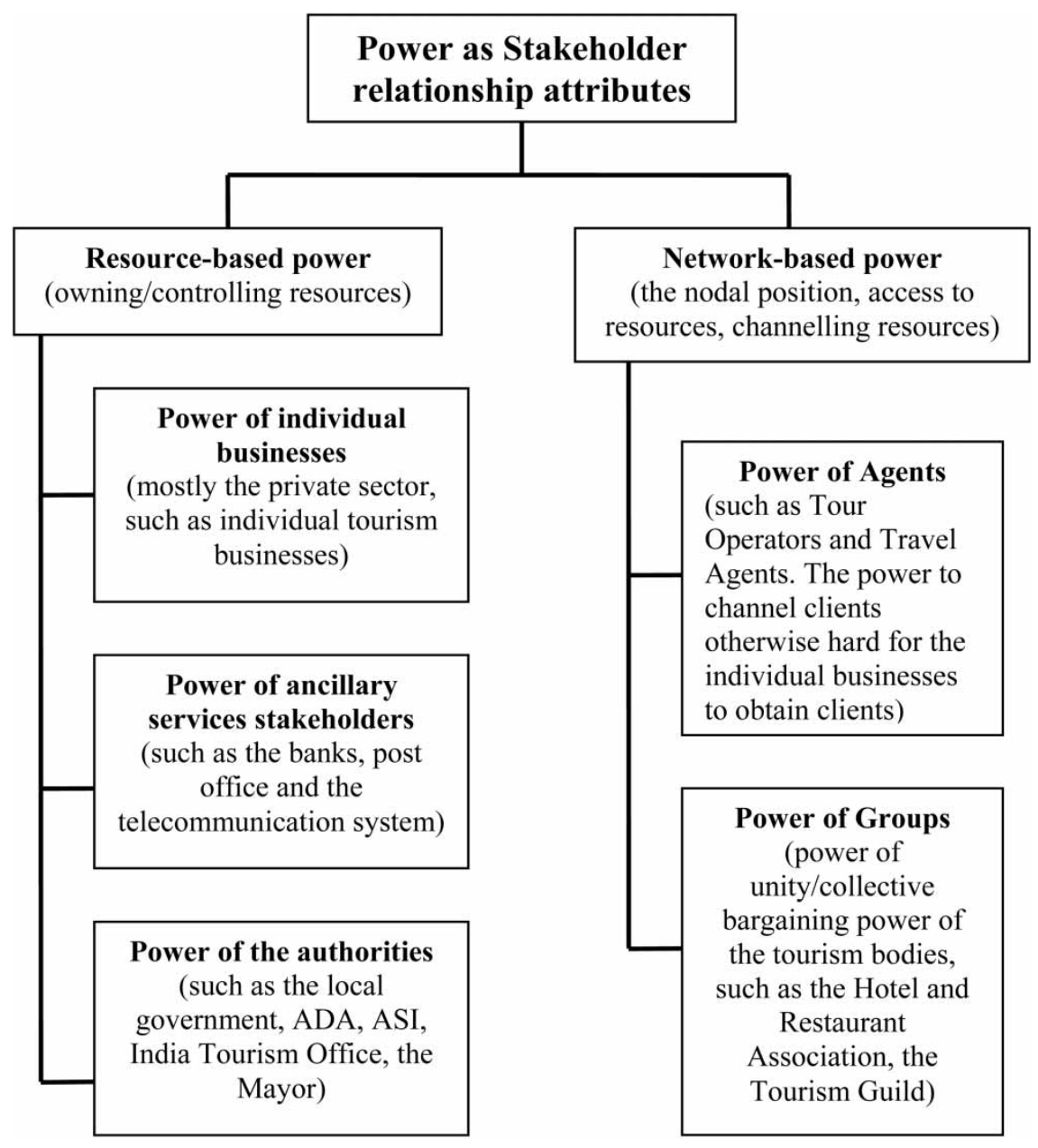

Figure 2. Power-relationship attributes.

\section{Conclusion}

This research adds knowledge and understanding to the power and dependency relationships among stakeholders. The literature review gives some indication of the stakeholder relationship attributes relating to resource- and structure-based power. This research analysed power relationships thematically from the interviews and offers a broad overview of the experiences of tourism stakeholders in Agra.

A key theme to emerge from the research is that the resource-based power of stakeholders can be classified according to the usage of resources, mainly in day-to-day, yearto-year and long-term tourism activities, labelled as power of individual businesses, power of ancillary services stakeholders and power of the authorities. The identification of day-to-day, year-to-year and long-term tourism resources would have major implications where individual and group stakeholders need to be consulted and corroborated at different levels and layers of tourism development for the long-term sustainability of the destination.

Furthermore, these findings also suggest that network-based power can be classified as the power of agents and power of groups; both of which have implications for the efficiency 
of the steady flow of resources, especially knowledge, information and clients. This type of classification (Figure 2) is particularly useful in a fragmented industry like tourism. This study is one of the first to apply both stakeholder management and network theory at the tourist destination/stakeholder level. This aids our understanding of power relationship attributes. Although this study is based on the Indian environment, where economic and social development is progressing rapidly, it also helps understand some of the issues that may arise in other developing nations.

Agra exhibits similar characteristics to other World Heritage destinations and, as such, the findings may have wider applicability. However, one of the limitations of this research would be of the sample; only willing people were interviewed, hence the findings could be biased because they do not take into account the views of those that did not participate. Also the research was conducted in summer (off-peak in Agra) which, although making it easier for the researcher to get appointment times from interviewees, their experience with relationships across the networks could vary in the busier times (resource-demanding situations).

Tourism is a multi-sector industry; a network of individuals and groups working towards a similar goal to provide products, services and experiences. However, these new classifications shed greater light on the issues associated with these goals and advance knowledge which in turn helps tourism development agencies (both private and public), destination management and marketing organisations, associated authorities and individual stakeholders in their daily operations and potential business opportunities.

It is particularly useful in the present economically challenging situation for stakeholders not only to source valued resources timely, but also to effectively enhance business activity, thereby securing the long-term success of the trade. However, further research is needed to test these emerging concepts in other tourist destinations where the major attraction is not under the control of local policy-makers or destinations.

\section{References}

Agra Calling. (2010). A book presented by the tourism guild of Agra for marketing purposes. Agra: The Tourism Guild of Agra.

Aitken, C., \& Hall, C. M. (2000). Migrant and foreign skills and their relevance to the tourism industry. Tourism Geographies, 2(1), 66-86.

Amit, R., \& Schoemaker, P. J. H. (1993). Strategic assets and organisational rent. Strategic Management Journal, 14(1), 33-46.

Amujo, O. C., \& Otubanjo, O. (2012). Leveraging rebranding of 'unattractive' nation brands to stimulate post-disaster tourism. Tourist Studies, 12(1), 87-105.

Bandyopadhyay, R., Morais, D. B., \& Chick, G. (2008). Religion and identity in India's heritage tourism. Annals of Tourism Research, 35(3), 790-808.

Brammer, N., \& Beech, J. (2004). Use and abuse of tourism: The goan experience. Tourism Culture and Communication, 5, 23-35.

Buhalis, D. (2000). Marketing the competitive destination of the future. Tourism Management, 21, 97-116.

Burkart, A. J., \& Medlik, S. (1981). Tourism past, present and future (2nd ed.). London: Heinemann.

Burney, J. B. (1991). Firm resources and sustained completive advantage. Journal of Management, 17(1), 99-120.

Carey, S., Guontas, Y., \& Gilbert, D. (1997). Tour operators and destination sustainability. Tourism Management, 18(7), 425-431.

Chaisawat, M. (2006). Policy and planning of tourism product development in Thailand: A proposed model. Asia Pacific Journal of Tourism Research, 11(1), 1-16.

Coles, T. E., \& Church, A. (2007). Tourism, power and space. London: Routledge.

Cooper, C. (2006). Knowledge management and tourism. Annals of Tourism Research, 33(1), 47-64. 
Cooper, C., Fletcher, J., Gilbert, D., Fyall, A., \& Wanhill, S. (2005). Tourism principles and practice (3rd ed.). Harlow: Pearson Education Limited.

Denzin, N., \& Lincoln, Y. (2000). The discipline and practice of qualitative research. In N. Denzin and Y. Lincoln (Eds.), Handbook of qualitative research (2nd ed.). London: Sage Publications.

Edensor, T. (1998). Tourists at the Taj: Performance and meaning at a symbolic site. London: Routledge.

Fill, C. (2006). Marketing communications: Engagements, strategies and practice (4th ed.). London: Pearson Education Ltd.

Fill, C., \& Fill, K. E. (2005). Business to business marketing: Relationships, systems and communications. Harlow: Prentice Hall.

Foster, C., McCabe, S., \& Dewhurst, H. (2010). Management development skills in the hospitality and tourism sector: Needs and issues from a regional perspective. Tourism and Hospitality Planning and Development, 7(4), 429-445.

Freeman, R. E. (1984). Strategic management: A stakeholder approach. Boston: Pitman.

Freeman, R. E. (1994). The politics of stakeholder theory: Some future directions. Business Ethics Quarterly, 4, 409-421.

Friedman, A. L., \& Miles, S. (2002). Developing stakeholder theory. Journal of Management Studies, $39(1), 1-21$.

Frooman, J. (1999). Stakeholder influence strategies. Academy of Management Review, 24(2), 191-205.

Fyall, A., Callod, C., \& Edwards, B. (2003). Relationship marketing: The challenge for destinations. Annals of Tourism Research, 30(3), 644-659.

Granovetter, M. D. (2004). The impact of social structures on economic development. Journal of Economic Perspectives, 19(1), 33-50.

Granovetter, M. S. (1973). The strength of weak ties. American Journal of Sociology, 78(6), $1360-1380$.

Granovetter, M. S. (1983). The strength of the weak tie: Revisited. Sociological Theory, 1, 201-233.

Gratton, C., \& Jones, I. (2007). Research methods for sport studies. London: Routledge.

Hannam, K. (2004). Tourism and forest management in India: The role of the state in limiting tourism development. Tourism Geographies, 6(3), 331-351.

Hannam, K., Sheller, M., \& Urry, J. (2006). Editorial: Mobilities, immobilities and moorings. Mobilities, 1(1), 1-22.

Harrison, J. S., Hitt, M. A., Hoskisson, R. E., \& Ireland, D. (2001). Resource complementarily in business combinations: Extending the logic to organisational alliances. Journal of Management, 27(6), 679-690.

Holden, A. (2010). Exploring stakeholders' perceptions of sustainable tourism development in the annapurna conservation area: Issues and challenges. Tourism and Hospitality Planning \& Development, 7(4), 337-351.

Holliday, A. (2007). Doing and writing qualitative research (2nd ed.). London: Sage Publications.

Kamat, P. (2002, October 23). Goa news: Government loan to tourism businesses. TNN (Times News Network) is the news agency of Times of India newspaper.

Kimbu, A. N., \& Ngoasong, M. Z. (2013). Centralised decentralisation of tourism development: A network perspective. Annals of Tourism Research, 40, 235-259.

Klaus, B.-E. (2006). A note on the separability principle in economics with single-peaked performances. Social Choice and Welfare, 26(2), 255-261.

Kotler, P., Bowen, J., \& Makens, J. (1999). Marketing for hospitality and tourism. Englewood Cliffs, NJ: Prentice Hall.

Luke, N. (2005). Confronting the 'Sugar Daddy' stereotype: Age and economic asymmetries and risky sexual behavior in Urban Kenya. International Family Planning Perspectives, 31(1), 6-14.

Miles, M. B., \& Huberman, A. M. (1994). An expanded sourcebook: Qualitative data analysis (2nd ed.). London: Sage Publications.

Mitchell, R. K., Agle, B. R., \& Wood, D. J. (1997). Toward a theory of stakeholder identification and salience: Defining the principle of who and what really counts. Academy of Management Review, 22(4), 853-886.

Morgan, M. (1996). Marketing for leisure and tourism. Essex: Prentice Hall Europe.

Nepal, S. K., \& Chipeniuk, R. (2005). Mountain tourism: Toward a conceptual framework. Tourism Geographies, 7(3), 313-333. 
Pajunen, K. (2006). Stakeholder influences on organisational survival. Journal of Management Studies, 43(6), 1261-1288.

Pavlovich, K. (2003). The evolution and transformation of a tourism destination network: The waitomo caves, New Zealand. Tourism Management, 24(2), 203-216.

Pavlovich, K. (2008). Network governance and connectivity: Acase study. In N. Scott, R. Baggio, \& C. Cooper, (Ed). Network analysis and tourism: From theory to practice. Clevedon: Channel View Publications.

Porter, M. (1985). Competitive advantage. New York: Free Press.

Ritchie, J. R. B., \& Crouch, G. I. (2005). The competitive destination: A sustainable tourism perspective. Wallingford, CT: CABI Publications.

Rowley, T. J. (1997). Moving beyond dyadic ties: A network theory of stakeholder influences. Academy of Management Review, 22(4), 887-910.

Saarinen, J. (2006). Traditions of sustainability in tourism studies. Annals of Tourism Research, 33(4), $1121-1140$.

Saunders, M., Lewis, P., \& Thornhill, A. (2009). Research methods for business students (5th ed.). Harlow: Financial Times Prentice Hall.

Sautter, E. T., \& Leisen, B. (1999). Managing stakeholders: A tourism planning model. Annals of Tourism Research, 26(2), 312-328.

Scherle, N., \& Coles, T. (2006). Inter-cultural communications and power relations in international tourism commodity chains. Zeitschrift fur Wirtschaftsgeographie, 50(2), 109-122.

Scott, J. (2006). Power: Key concepts. Cambridge: Polity press.

Scott, N., Cooper, C., \& Baggio, R. (2008). Network analysis and tourism: From theory to practice. Clevedon: Channel View Publications.

Silverman, D. (2006). Interpreting qualitative data: Methods for analysing talk, text and interaction (3rd ed.). London: Sage Publications.

Stampe, J. (2008). Views from here: Working in the field, looking for tourists, mapping touristic terrain. Tourist Studies, 8(1), 123-140.

Stern, L. W., \& El-Ansary, A. I. (1992). Marketing channels (4th ed.). London: Prentice Hall International.

Tsai, P. C. F., Yeh, C. R., Shu-Ling, W., \& Ing-Chung, H. (2005). An empirical test of stakeholder influence strategy models: Evidence from business downsizing in Taiwan. International Journal of Human Resource Management, 16(10), 1862-1885.

Ujma, D. (2001). Theoretical overview: Distribution channels for tourism. In E. Laws \& D. Buhalis (Eds.), Tourism distribution channels: Practices, issues and transformations. London: Continuum.

Weiermair, K. (2005). Prospects for innovation in tourism: Analyzing the innovation potential throughout the tourism value chain. Journal of Quality Assurance in Hospitality and Tourism, $6(3-4), 59-72$.

Weiermair, K. (2006). Product improvement or innovation: What is the key to success in tourism? In OECD (Eds.), Innovation and growth in tourism (pp. 53-67). Paris: OCED Publishing.

Wilson, E., \& Little, D. E. (2008). The sole female travel experience: Exploring the 'Geography of Women's Fear'. Current Issues in Tourism, 11(2), 167-186.

Yin, R. K. (2003). Case study research: Design and methods (3rd ed.). London: Sage Publications.

Zapata, M. J., Hall, C. M., Lindo, P., \& Vanderschaeghe, M. (2011). Can community-based tourism contribute to development \& poverty alleviation? Lessons from Nicaragua. Current Issues in Tourism, 14(8), 725-749. 